\title{
Marina Krasnoperova: A Trodden Path
}

\author{
Evgenij Kazartsev \\ Tatjana Voevodskaja
}

Marina Abramovna Krasnoperova-Eidel (1941-2010) was an extraordinary scholar who worked at the junction of linguistics, poetics and mathematics, entirely devoting herself to a special area of knowledge: verse prosody. Being a pupil of the celebrated Russian mathematician Andrei Kolmogorov, she had blazed new trails in this science. Since her student years she had been studying the rhythmic system of poetic speech using for its analysis a sophisticated mathematical apparatus. She believed that mathematics would permit the philological science to penetrate into the depths of human consciousness through text analysis.

Some colleagues of Dr. Krasnoperova did not recognise or half recognised her contribution to science, not sharing her views on the nature and structure of verse. Others, on the contrary, believed she was ahead of her time with her theory of reconstructive simulation of versification, which became a milestone in the theory of verse and made its author one of the founders of cognitive poetics.

Marina Krasnoperova was contemporary of Joseph Brodsky whose poetry she highly appreciated and with whom her brother Sergey Krasnoperov, a Leningrad poet, was on friendly terms. She was born on December 20, 1940 in Leningrad, into a family of mining engineers Galina Krasnoperova and Abram Eidel, who by then already had two sons. In 1945 the father died and the care of the children and their education fell entirely on the mother's shoulders. In 1958 Marina became student of the first-ever Department of Mathematical Linguistics opened at the Faculty of Philology within the Leningrad State University. There her teachers were an outstanding phonologist and the founder of the Department L. R. Zinder, a remarkable linguist Yu.S. Maslov, noted mathematicians I. A. Ibragimov, G. S. Tseytin, S. Ya. Fitialov, and other scholars, themselves co-founders of mathematical linguistics. A promising student, she was sent to Moscow State University where she worked on her Master's thesis under the guidance of Andrei Kolmogorov.

In the following years, her life and research were closely associated with Moscow and the Moscow school of linguistics. In the late 60s, Marina Krasnoperova studied poetic speech at the Institute of Slavic and Balkan Studies at the Academy of Sciences of the USSR under the guidance of Vyacheslav V. Ivanov. Only in the early 70s did she come back to Leningrad. 
Since then, and until her death, she had been working at the Laboratory of Mathematical Linguistics (later named Laboratory of Intellectual Systems) of the Institute of Mathematics and Mechanics at St. Petersburg State University. From 2001 to 2010 she was the Head of this Laboratory.

Marina Krasnoperova defended her PhD thesis rather late, only in 1981. However, this work was very unusual and advanced. It contained fundamentals of an absolutely new science on processes of the perception and generation of poetic speech. Later, in a series of works, she elaborated the so-called Theory of Reconstructive Simulation (RS) of Versification, which became the basis of this science and took its final shape in her post-doctoral thesis for the Dr hab. degree of 1992 and also in the monograph of 2000.

With the help of her theory of RS, and of her unique research apparatus, Marina Krasnoperova managed to make important discoveries in prosody. One of her brightest achievements was an explanation of the law of regressive accentual dissimilation formulated by Kiril Taranovsky in 1953 (Krasnoperova 1982). Many scholars, including Taranovsky himself, recognised the reliability of Krasnoperova's methods as they had shown a gradual development of regressive accentual dissimilation in the verse.

The scientific device of reconstructive simulation of versification is based on a series of semiotic, probabilistic-statistical and cybernetic models. Probabilisticstatistical models are constructed on the basis of the rhythmic dictionary of prose or poetry. Among the cybernetic models, the model of generation and perception of rhythmical structures is a leading one. To the cognitive processes represented in this model one puts in correspondence the probabilistic-statistical data, which are interpreted in the framework of the theory of RS. The theoretical apparatus developed by Krasnoperova, and the results obtained by her, permitted a hypothetical reconstruction of the mechanism of versification at the level of rhythm to understand the causes of the evolution of the verse connected with the probabilistic properties of the Russian language, the particularities of the verse generation process, and the nature of rhythmic effects.

From the beginning of her work at St. Petersburg State University Marina Krasnoperova was actively engaged in teaching activities both at the Faculty of Mathematics and Philology. She was professor in both Faculties. She had many pupils and found great satisfaction working with them. She prepared and delivered many new courses on prosody and linguistic poetics. Some of them were published as tutorials (Krasnoperova 1989, 2004).

For several years Marina Krasnoperova headed the Association of Verse Theorists created at the St. Petersburg Linguistic Society. From 2000 to 2010 she was the head of the permanent international seminar "Linguistics and Applied Poetics" at the Institute of Russian Literature of the Russian Academy 
of Sciences. In 1998 she was the initiator and leading organiser of a big international conference "Slavic Verse: Linguistics and Applied Poetics in the System of Modern Sciences".

Marina Krasnoperova was awarded numerous fellowships, including grants from the Russian Foundation for Basic Research (RFFI) and the German Academic Exchange Service (DAAD), as well as a Fulbright Research grant (University of Wisconsin, USA). She delivered a course of lectures at the Department of Theoretical and Applied Linguistics (Moscow State University), taught at the Universities of Washington and Chicago. In 1999, Marina Krasnoperova was awarded a medal and a Diploma of Merit "for high scholarly achievements and in connection with the 275 anniversary of St. Petersburg State University". In 1987 her work was noted in the questionnaire "Results and problems of semiotic research" (Sign Systems Studies, vol. 20) as the greatest achievement in the study of the verse by exact methods in the last 25 years. In 1997, International Journal of Slavic Linguistics and Poetics made special mention of her works as innovative in the field of prosody and theory of verse.

In 2004 a noted phonologist, L. V. Zlatoustova, published an article on this new branch of the theory of verse, in which she highly appreciated Krasnoperova's contribution to the field (Zlatoustova 2004). According to Zlatoustova, the theory of reconstructive simulation of versification represents "a new paradigm in modern prosody". Besides, in different years the works of Krasnoperova received a high appraisal from such scholars as Yu. M. Lotman, V. S. Bayevsky, and M. L. Gasparov.

It should be noted that the theory of reconstructive simulation opened new prospects in studying not only Russian versification: its application allows the possibility to describe the typology of mechanisms of versification in different languages (Krasnoperova, Kazartsev 2011). With the help of this theory Evgenij Kazartsev is carrying out a broad study of the formation and development of syllabo-tonics in European poetry (Kazartsev 2013, 2014).

A very promising application of this theory is also the study of semantics of rhythm, the description of rhythmic effects and detection of their semantic predispositions (see Krasnoperova 2003; Krasnoperova, Shljushenkova 2004). In the last decade Marina Krasnoperova together with a group of physicists and mathematicians studied the possibilities of neural networks for an analysis of processes simulated in the theory of RS (Krasnoperova et al. 2001; Krasnoperova, Granichin 2001).

Marina Krasnoperova died suddenly, in the 70th year of life, at full strength. This happened on June 30, 2010. She liked to repeat: "How it is difficult to be a pioneer!" And continued addressing her pupils: "I hope, for you it will be easier!" Perhaps, she was partly right; a well-trodden path is easier to traverse. 
However, with her passing the academic life of her pupils became more difficult. At times, it is hard for them to find understanding in their professional media. Some colleagues have a watchful attitude to the formal analysis: how can one explain poetry with the help of mathematics? A quantitative character of the technique and a nontrivial logic used in the analysis and interpretation of results obtained also causes difficulties in comprehension. Nevertheless, the theory of RS is now an actively developing branch of science. The pupils of Marina Krasnoperova in different countries continue on the path she made easier, one so well trodden by her.

\section{References}

Kazartsev, Evgenij 2013. Niederländische Quellen von Martin Opitz' Versrhythmik. In: Zeitschrift für Germanistik 3, 118-128.

Kazartsev, Evgenij 2014. Comparative Study of Verse: Language Probability Models. In: Style 48, 119-139.

Krasnoperova, Marina Abramovna 1982. K voprosu o zakone regressivnoj akcentnoj dissimiljacii i ego prichinakh. In: Russian Literature 12, 2, 217-225.

Krasnoperova, Marina Abramovna 1989. Modeli lingvisticheskoj poetiki. Ritmika: Uchebnoe posobie. Leningrad: Izdatel'stvo Leningradskogo gosudarstvennogo universiteta.

Krasnoperova, Marina Abramovna 2000. Osnovy rekonstruktivnogo modelirovanija stikhoslozhenija. Na materiale ritmiki russkogo stikha. Sankt-Peterburg: Izdatel'stvo Sankt-Peterburgskogo gosudarstvennogo universiteta.

Krasnoperova, Marina Abramovna 2003. O principakh komp'juternogo modelirovanija semantiki ritmicheskogo teksta. In: Trudy II Mezhdunarodnoj konferencii "Identifikacija sistem i zadachi upravlenija". Moskva: Institut problem upravlenija, 1768-1780.

Krasnoperova, Marina Abramovna 2004. Osnovy sravnitel'nogo statisticheskogo analiza ritmiki prozy i stikha: Uchebnoe posobie. Sankt-Peterburg: Izdatel'stvo SanktPeterburgskogo gosudarstvennogo universiteta.

Krasnoperova, Marina Abramovna; Shljushenkova (Voevodskaja), Tat'jana Borisovna 2004. O semanticheskikh otnoshenijakh ritmoobrazujushchikh edinic v russkoj poezii XIX-XX vv. In: Slavjanskij stikh: VII. Lingvistika i struktura stikha. Moskva: Jazyki slavjanskoj kul'tury, 319-338. 
Krasnoperova, Marina Abramovna; Pis'mak Juri M.; Chernykh German Anatol'evich 2001. O vozmozhnosti primenenija modelej nejronnykh setej v issledovanii ritmiki teksta. In: Scherr, Barry P. and Kazarcev, Evgenij (eds.), Formal'nye metody $v$ lingvisticheskoj poetike. Sankt-Peterburg. Izdatel'stvo Sankt-Peterburgskogo gosudarstvennogo universiteta, 11-27.

Krasnoperova, Marina Abramovna; Granichin, Oleg Nikolaevich 2001. Primenenie algoritma stokhasticheskoj approksimacii s odnovremennym vozmushcheniem na vkhode v rekonstruktivnom modelirovanii stikhoslozhenija. In: Formal'nye metody $v$ lingvisticheskoj poetike. Sankt-Peterburg. Izdatel'stvo Sankt-Peterburgskogo gosudarstvennogo universiteta, 28-38.

Krasnoperova, Marina Abramovna; Kazartsev, Evgenij 2011. Reconstructive simulation of versification in comparative studies of texts in different languages (theoretical aspects and practice of application). In: Lotman, Mihhail; Lotman, Maria-Kristiina (eds.), Frontiers in Comparative Metrics. In memoriam: Mikhail Gasparov. Linguistic insights 113. Bern [etc.]: Peter Lang, 97-120.

Zlatoustova, Ljubov' Vladimirovna 2004. O novom napravlenii v stikhovedenii: Teorija rekonstruktivnogo modelirovanija stikhoslozhenija. In: Vestnik Moskovskogo universiteta. Serija 9: Filologija 5, 122-125. 